\title{
Improving Investment Management in Agribusiness
}

\author{
OLESYA FINAGINA ${ }^{1}$, LARYSA PRODANOVA*2, OLHA ZINCHENKO ${ }^{3}$, IEVGEN BURIAK ${ }^{4}$, \\ OLEKSANDR GAVRYLOVSKYI ${ }^{5}$, YULIIA KHOROSHUN ${ }^{6}$ \\ 1,2,6 Department of Management and Business Administration, CHERKASY STATE TECHNOLOGICAL UNIVERSITY, \\ UKRAINE. *E-mail: lesya.finagina@ukr.net \\ ${ }^{3}$ Department of Marketing and International Management, OLES HONCHAR DNIPRO NATIONAL UNIVERSITY, \\ UKRAINE. \\ ${ }^{4}$ Department of Management, KREMENCHUK MYKHAILO OSTROHRADSKYI NATIONAL UNIVERSITY, UKRAINE. \\ ${ }^{5}$ Department of International Accounting and Audit, KYIV NATIONAL ECONOMIC UNIVERSITY NAMED AFTER \\ VADYM HETMAN, UKRAINE.
}

\begin{abstract}
The financial condition of many agricultural organizations does not allow financing investments at the expense of funds; therefore, there is a need for investments, borrowed sources of investment financing are too expensive. Therefore, the issue of improving investment management in agribusiness is incredibly urgent. To develop proposals, the authors analyzed theoretical studies in this area, as well as the state of agribusiness in Ukraine and investment trends. Based on the study, the authors proposed a mechanism for improving investment management in agribusiness, the distinctive features of which are the cooperation of internal and external sources, as well as risk management due to the specifics of the industry. Using a practical example, the authors showed an example of risk management in agriculture, which confirmed that taking risks into account leads to the more correct and effective planning of investment activities.
\end{abstract}

Keywords: agribusiness, investment, management, risk.

JEL Classification: Q14, E22, D81.

Received: 6 April 2021

Accepted: 14 April 2021 


\section{Introduction.}

The financial condition of agricultural organizations (creditworthiness, unprofitable production, overdue receivables and payables) does not allow them to finance investments from their own profits, depreciation does not provide the necessary resources for the renewal process, and borrowed sources of investment financing are too expensive. A significant decline in the agricultural sector's investment potential has brought the material and technical base to a critical level (Korauš et al., 2020). The efficiency of production of all types of agricultural products has significantly decreased. The number of unprofitable agricultural organizations has increased. Imports dominate the agrarian market of Ukraine, which also harms the country's food security (Kvasha et al., 2019; State Statistics Service of Ukraine, 2021). The key factor in the agribusiness's exit from the crisis in the medium and long term should be to increase production efficiency, which is impossible without the introduction of new technologies based on updated and modern material and technical base. In this regard, the improvement of agricultural policy, stimulation of investment activities and growth of investment potential of agricultural organizations will provide favourable conditions for agribusiness development.

In this regard, the development and scientific substantiation of measures to promote the development of investment activities in agribusiness in conditions of instability and economic crisis are becoming especially important. Different stages of investment activity involve the use of different types of financial security. Special attention should be paid to risk management in conditions of instability, especially in the management of investment activities (Fillypova et al., 2019). Thus, the study aims to find ways to improve investment management in agribusiness.

\section{Theoretical and analytical basis of investment management in agribusiness.}

The investment process, like any other, needs to be managed. Management is a process by which any system is influenced to maintain it in a particular state or transfer it to a new state that will correspond to the objective laws inherent in this system and specific goals (Almazán et al., 2017). More specifically, control is understood as a set that includes laws, goals, functions, structures, principles, methods and forms, with the help of which a process is influenced (Merchant, 1982; Ford, 2019).

Control laws are an objective necessity in nature and society. The use of laws allows you to organize any activity in such a way as to achieve the set goals most effectively. The management principles follow from the laws, which consist of the main guidelines, rules based on the operation of objective laws, according to which management activities are carried out, and management systems are built. Goals are the ideal end result that the subjects of management strive for. After the goal is set, the solution of many tasks follows. Tasks are a collection of questions and conditions. They are solved by means of specific methods. In our case, the methods of purposeful influence of the subject of control on the control object maintain its stability in the specified modes of operation during the transfer from one state to another and achieve a certain goal. The methods are implemented with the help of functions, which are specialized type of activity, the object of which is social and economic relations (Zakharova, 2014; Dzwigol et al., 2019).

Investment process management is understood as a system that includes organizational structures and organizational and economic relations, influencing the investment process to achieve economic, social, and other interests. Management of investment processes in market conditions has a certain sequence and is divided into state and economical, which, in turn, are divided into territorial and sectoral (functional) (Winch, 2007; Mattila et al., 2008; Oleshko et al., 2020).

The fundamental role of investment processes is associated with the fact that investment projects form the structure of production in the agro-industrial complex, and therefore the main changes occurring during the transition of the domestic economy to a market one primarily relate to the process of making investment decisions. The national economic approach, characteristic of a planned economy, is replaced by a mechanism for making investment decisions at the level of organizations 
as full-fledged market relations subjects, which independently pursue their investment policy and bear financial responsibility for its results (Tworek, 2014; Serhienko, 2020). The main goal of managing investment processes in the agro-industrial complex at the micro-level is to provide the most effective ways to implement the organization's investment strategy. Realizing the main goal in the management of investment processes is necessary to carry out the following measures, namely: to ensure high rates of economic development of the organization through effective investment activities; to ensure the maximization of income (profit) from investment activities; ensure the minimization of risks; ensure the financial stability and solvency of the organization in the course of the implementation of investment activities; to find ways by which it is possible to accelerate the implementation of investment projects.

At the micro-level, the investment policy consists of a set of measures that provide a profitable investment of own, borrowed, and other funds in investments to ensure the organization's stable financial stability in the short term.

The state manages investment processes based on the existing legal framework. A good regulatory framework is a fundamental foundation for managing investment processes. The regulatory framework in the field of investment activity, created during the transition to a market economy, has played and continues to play a significant positive role in the development of the processes taking place in the country in the field of investment activity.

The problems that have arisen in the agro-industrial complex's investment sphere are a mirror image of the ongoing crisis in the economy. They are accompanied by underinvestment in the real sector, a reduction in agricultural products production, disruption of reproduction processes in agriculture, animal husbandry and related industries, which significantly reduces the production potential of the industry and increases the country's food dependence (Fig. 1).

Figure 1. Dynamics of production volume of cereal and leguminous crops as of 01 December 2021

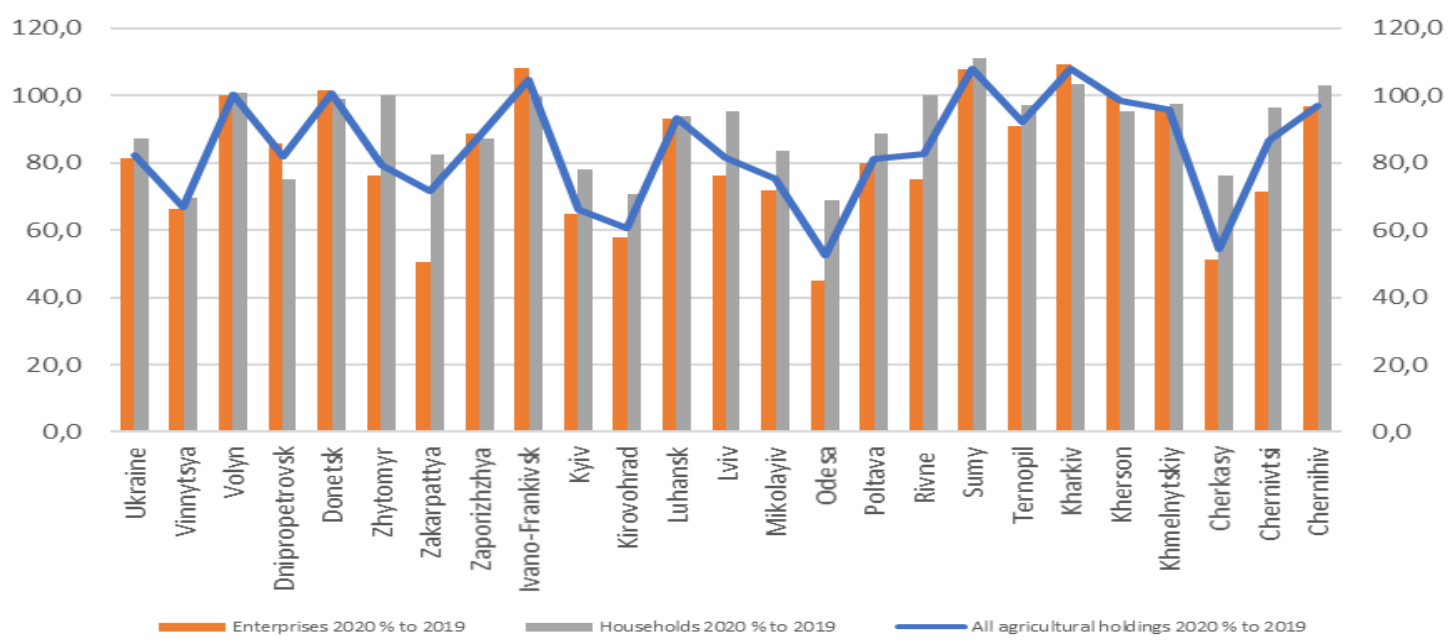

(source: developed by the authors based on the data of the State Statistics Service of Ukraine, 2021)

In some regions, there is a positive trend, which indicates that with the correct distribution of investment, it is possible to scale, under certain conditions, prosperous regions' experience to others (Table 1).

Investments are a multidimensional economic category, which is an essential component of the mechanism of functioning of the agricultural sector of the economy, which determines the degree of economic development of the country and directly affects the modern financial sphere development of regulatory instruments. A balanced investment and innovation policy in the economy's agricultural sector is one of the crucial prerequisites for ensuring the country's economic and food security. 
Table 1. Harvesting of cereal and leguminous crops as of 01 December 2020

\begin{tabular}{|c|c|c|c|c|c|c|c|c|c|}
\hline \multirow[b]{2}{*}{ REGION } & \multicolumn{3}{|c|}{ ALL AGRICULTURAL HOLDINGS } & \multicolumn{3}{|c|}{ ENTERPRISES } & \multicolumn{3}{|c|}{ HOUSEHOLDS } \\
\hline & $\begin{array}{l}\text { harveste } \\
\text { d area, } \\
\text { thsd.ha }\end{array}$ & $\begin{array}{l}\text { volume of } \\
\text { production, } \\
\text { thsd. centner }\end{array}$ & $\begin{array}{c}\text { yield, } \\
\text { centner per } \\
\text { ha of the } \\
\text { harvested } \\
\text { area }\end{array}$ & $\begin{array}{c}\text { harvested } \\
\text { area, } \\
\text { thsd.ha }\end{array}$ & $\begin{array}{l}\text { volume of } \\
\text { production, } \\
\text { thsd. centner }\end{array}$ & $\begin{array}{c}\text { yield, } \\
\text { centner per } \\
\text { ha of the } \\
\text { harvested } \\
\text { area }\end{array}$ & $\begin{array}{c}\text { harveste } \\
\text { d area, } \\
\text { thsd.ha }\end{array}$ & $\begin{array}{l}\text { volume of } \\
\text { production, } \\
\text { thsd. centner }\end{array}$ & $\begin{array}{c}\text { yield, } \\
\text { centner per } \\
\text { ha of the } \\
\text { harvested } \\
\text { area }\end{array}$ \\
\hline UKRAINE & 14759,1 & 633445,4 & 42,9 & 10619,8 & 498761,6 & 47,0 & 4139,3 & 134683,8 & 32,5 \\
\hline VINNYTSYA & 856,5 & 40675,3 & 47,5 & 687,3 & 34654,2 & 50,4 & 169,2 & 6021,1 & 35,6 \\
\hline VOLYN & 298,5 & 13347,1 & 44,8 & 138,7 & 8571,4 & 61,8 & 159,8 & 4775,7 & 29,9 \\
\hline $\begin{array}{c}\text { DNIPROPETROVS } \\
K\end{array}$ & 1093,4 & 35732,6 & 32,7 & 656,1 & 24622,7 & 37,5 & 437,3 & 11109,9 & 25,4 \\
\hline DONETSK & 568,6 & 20143,5 & 35,4 & 395,2 & 14722,1 & 37,3 & 173,4 & 5421,4 & 31,3 \\
\hline ZHYTOMYR & 467,6 & 22864,9 & 48,9 & 356,8 & 19063,0 & 53,4 & 110,8 & 3801,9 & 34,3 \\
\hline ZAKARPATTYA & 70,8 & 2896,4 & 40,9 & 9,6 & 698,2 & 72,3 & 61,2 & 2198,2 & 35,9 \\
\hline ZAPORIZHZHYA & 983,4 & 29962,5 & 30,5 & 705,5 & 22551,6 & 32,0 & 277,9 & 7410,9 & 26,7 \\
\hline $\begin{array}{l}\text { IVANO- } \\
\text { FRANKIVSK }\end{array}$ & 146,5 & 7955,5 & 54,3 & 78,8 & 4957,5 & 62,8 & 67,7 & 2998,0 & 44,4 \\
\hline KYIV & 624,8 & 28980,3 & 46,4 & 529,1 & 25477,9 & 48,2 & 95,7 & 3502,4 & 36,6 \\
\hline KIROVOHRAD & 839,5 & 26712,8 & 31,8 & 631,1 & 20346,6 & 32,2 & 208,4 & 6366,2 & 30,6 \\
\hline LUHANSK & 391,4 & 13765,7 & 35,2 & 307,5 & 11255,1 & 36,6 & 83,9 & 2510,6 & 29,9 \\
\hline LVIV & 280,2 & 13939,5 & 49,7 & 163,7 & 9500,9 & 58,0 & 116,5 & 4438,6 & 38,1 \\
\hline MIKOLAYIV & 877,8 & 23955,6 & 27,3 & 577,8 & 16185,0 & 28,0 & 300,0 & 7770,6 & 25,9 \\
\hline ODESA & 1046,8 & 20207,1 & 19,3 & 660,5 & 11761,0 & 17,8 & 386,3 & 8446,1 & 21,9 \\
\hline POLTAVA & 988,9 & 50492,0 & 51,1 & 771,4 & 41086,0 & 53,3 & 217,5 & 9406,0 & 43,3 \\
\hline RIVNE & 252,5 & 12646,4 & 50,1 & 124,8 & 7987,4 & 64,0 & 127,7 & 4659,0 & 36,5 \\
\hline SUMY & 670,9 & 48563,8 & 72,4 & 597,1 & 45413,7 & 76,1 & 73,8 & 3150,1 & 42,7 \\
\hline TERNOPIL & 445,7 & 25555,3 & 57,4 & 299,8 & 19771,9 & 66,0 & 145,9 & 5783,4 & 39,6 \\
\hline KHARKIV & 1008,8 & 48497,6 & 48,1 & 720,2 & 36462,4 & 50,6 & 288,6 & 12035,2 & 41,7 \\
\hline KHERSON & 774,9 & 27321,5 & 35,3 & 489,2 & 18590,4 & 38,0 & 285,7 & 8731,1 & 30,6 \\
\hline KHMELNYTSKIY & 576,1 & 38146,9 & 66,2 & 479,1 & 34042,8 & 71,1 & 97,0 & 4104,1 & 42,3 \\
\hline CHERKASY & 651,6 & 25339,8 & 38,9 & 526,0 & 20913,0 & 39,8 & 125,6 & 4426,8 & 35,3 \\
\hline CHERNIVTSI & 116,8 & 5668,0 & 48,4 & 40,9 & 1817,2 & 44,2 & 75,9 & 3850,8 & 50,7 \\
\hline CHERNIHIV & 727,1 & 50075,3 & 68,9 & 673,6 & 48309,6 & 71,7 & 53,5 & 1765,7 & 32,9 \\
\hline
\end{tabular}

(source: developed by the authors based on the data of the State Statistics Service of Ukraine, 2021)

The functional role of the investment process in the structure of social reproduction consists in transforming free financial resources into updating and improving the fundamental factors of production and ensuring, on this basis, sustainable GDP growth.

Consider the sources of investment in agribusiness enterprises (Fig. 3).

Unfortunately, the statistics do not reflect the real picture, because data concerning Capital investments due to state budget funds, funds of investment companies, fund and funds of nonresident investors are not published to ensure compliance with the requirements of the Law of Ukraine On the State Statistics regarding confidentiality of statistical information.

The analysis shows that more than $90 \%$ of investments are own investments of enterprises. There are several reasons for this: 
Figure 3. Capital investments by financing sources in agribusiness in January-December 2020, thsd. UAH

\section{Crop production and related service activities}

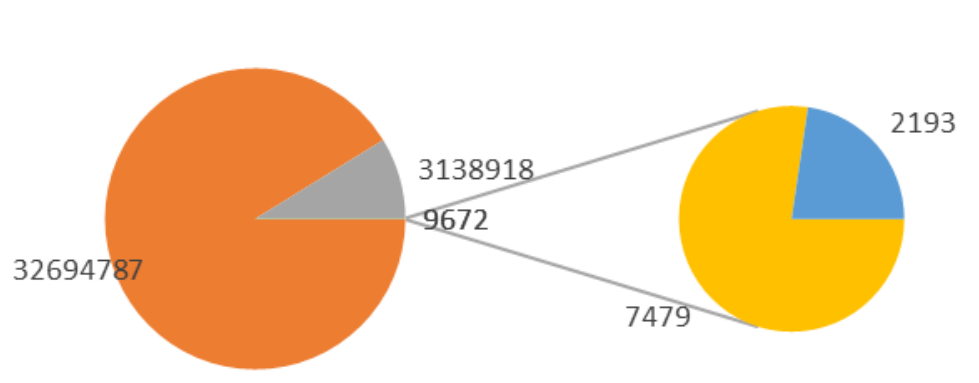

a others

n own funds of enterprises and organizations

credit funds and other position

w other sources of funding

a funds from local budgets

(source: developed by the authors based on the data of the State Statistics Service of Ukraine, 2021)

\section{Methodology.}

Agriculture is a key and vital sector of social production, and at the same time, one of the riskiest sectors of the economy, as the reproductive process is associated with climatic and biological factors.

Figure 4. The mechanism for improving the management of investments in agribusiness

\begin{tabular}{|c|c|c|c|}
\hline \multicolumn{2}{|r|}{$\begin{array}{l}\text { Mechanisms for improving the } \\
\text { attraction of investment resources }\end{array}$} & & Main measures \\
\hline \multicolumn{2}{|r|}{$\underset{\mathbf{v}}{\text { Internal }}$} & $\begin{array}{l}\text { mobilization of own } \\
\text { investment resources }\end{array}$ & $\begin{array}{l}\text { intensification of the processes of formation } \\
\text { and use of own funds for investment purposes }\end{array}$ \\
\hline \multirow{5}{*}{\multicolumn{2}{|c|}{\begin{tabular}{|c|} 
formation of investment policy \\
in the appropriate management \\
system within organizational \\
investment processes, \\
implementation of measures to \\
improve the financial condition, \\
increase creditworthiness and \\
investment attractiveness
\end{tabular}}} & \multirow{3}{*}{\begin{tabular}{|c|} 
studying of the possibility \\
and attraction of Ukrainian \\
and foreign investment \\
resources of investors
\end{tabular}} & $\begin{array}{c}\text { in the form of special development funds, profit } \\
\text { and depreciation deductions }\end{array}$ \\
\hline & & & improving financial discipline \\
\hline & & & $\begin{array}{l}\text { assessment of opportunities and attraction of } \\
\text { financial production-oriented investments }\end{array}$ \\
\hline & & expanding the use of credit & increase the authorized capital \\
\hline & & institutions' resources & use of investment leasing in the supply of \\
\hline \multicolumn{2}{|r|}{ External } & \multirow{3}{*}{$\begin{array}{l}\text { more active use of } \\
\text { Ukrainian and foreign } \\
\text { investors }\end{array}$} & \multirow{2}{*}{ joint ventures creating } \\
\hline \multirow{4}{*}{ 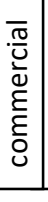 } & \multirow{4}{*}{$\begin{array}{l}\text { economic stimulation of } \\
\text { investment activity of } \\
\text { commercial structures within } \\
\text { the framework of innovative } \\
\text { development programs }\end{array}$} & & \\
\hline & & & use of insurance instruments \\
\hline & & & building a risk management culture \\
\hline & & $\begin{array}{l}\text { creation of a risk } \\
\text { management system }\end{array}$ & mprovement of the financial guarantee system \\
\hline \multirow{5}{*}{ 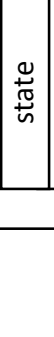 } & \multirow{5}{*}{$\begin{array}{l}\text { territorial and sectoral } \\
\text { regulation and support of } \\
\text { innovative development } \\
\text { processes }\end{array}$} & \multirow{5}{*}{$\begin{array}{l}\text { creation of preferential } \\
\text { conditions for the use of } \\
\text { financial resources of the } \\
\text { credit investment system }\end{array}$} & $\begin{array}{l}\text { fundraising within the framework of the agro- } \\
\text { industrial complex development program }\end{array}$ \\
\hline & & & $\begin{array}{l}\text { participation in competitions held by } \\
\text { government agencies }\end{array}$ \\
\hline & & & fulfilment of government orders \\
\hline & & & execution of the concessional lending system \\
\hline & & & $\begin{array}{c}\text { expanding the use of lease financing } \\
\text { mechanisms }\end{array}$ \\
\hline
\end{tabular}

(source: developed by the authors)

The peculiarity of this business is the extreme risk. In addition to the risks inherent in any business, there are specific ones. According to its characteristics, agricultural risks can be fully classified as risks that pose a risk of damage to an agricultural enterprise (or farm of an agricultural producer) due to the disruption of the production process's normal course. Peculiarities of agricultural risk are determined by the specifics of production in the industry. Suppose for industry, 
the most serious violations of the production process are the failure of machinery and equipment, emergencies, then for agricultural production. In that case, such violations are changes in the processes of organogenesis (growth and development of plants) in crop production, leading to damage and death of crops. In animal husbandry, disruption of production processes leads to disease and death of animals. Regional features significantly affect the location of crop production (specialization of regions is considered based on the existing classification. Each region of the country is characterized by specialization and proportionality of business activity. Territorial and socioeconomic parameters of specialization of regions reflect the role of each region in agriculture).

Thus, we believe that investment management should be improved through risk management; also, to enhance investment activity is necessary to use both internal and external mechanisms (Fig. 4).

This mechanism will make it possible to manage the investment support of enterprises more effectively. The development of the enterprise's investment opportunities, the expansion of the use of progressive investment instruments, the combination with the optimization of production and sales activities within the integrated interests of all members of the formations should ensure the successful implementation of the adopted investment strategy.

\section{Results and discussion.}

Consider risk-based investment management in agribusiness. According to the latest financial report of agricultural Ltd. "ZORYA" (Cherkasy region, maize cultivation) production costs (excluding interest on the loan) amounted to $\$ 202,480$, or $\$ 216,76$ per 1 hectare of grain crops. Annually, the company must now spend $\$ 85,000$ to pay interest $(\$ 55,000)$ and repay the principal debt $(\$$ $30,000)$. At the beginning of 2021 , the average price of a ton of corn is $\$ 284$, i.e. $\$ 28,4$ per quintal. To cover production costs, the company must obtain a yield of $7.63 \mathrm{~kg} / \mathrm{ha}(202,480 / 934,23 / 28,4)$.

To assess the vulnerability of the agricultural enterprise to risk, a number of indicators are given for the enterprise as a whole and for 1 ha of grain sowing (Table 2).

Table 2. Performance indicators of the enterprise to calculate its vulnerability to risk

\begin{tabular}{r|ccc}
\multicolumn{2}{c}{ INDICATOR } & TOTAL & PER 1 HECTARE OF CORN \\
\hline CORN SOWING AREA, HA & 934,23 & $\mathrm{X}$ \\
ASSETS, \$ & 975840 & 1044,54 \\
DEBT, \$ & 425125 & 455,05 \\
EQUITY, \$ & 125000 & 133,80 \\
ANNUAL REPAYMENT OF PRINCIPAL AND INTEREST ON THE LOAN, \$ & 85000 & 216,73 \\
PRODUCTION COSTS, \$ & 202480 & 90,98
\end{tabular}

Risk vulnerability assessment. As you can see from table 2 , the company must annually spend $\$$ 90,98 per hectare on debt service. To determine what yield will provide sufficient revenue only to cover production costs and debt obligations, you must first sum these costs. At the enterprise they make $\$ 307,71(216,73+90,98)$. The result means that the company must receive $\$ 307,71$ to reimburse these costs revenue per 1 hectare of crops. This can be achieved if the company achieves a grain yield of $10.83 \mathrm{~kg} / \mathrm{ha}(307,71 / 28,4)$ at an average market price.

Since the company's main source of risk is possible fluctuations in yields and prices, it is important to analyze whether it will have any advantages if the insurance company insures the crop in case of its low level.

Identification of sources of risk. In addition to actual data on yield for the enterprise and grain prices for the last 10 years, the surveyed enterprise also received the statistical service information on the probability of yield levels in the region where it is located (Table 3). 
Table 3. Probability of obtaining yield levels in the region where the researched enterprise is located

\begin{tabular}{|c|c|c|c|c|c|}
\hline Yield, c/ha & $\begin{array}{c}\text { Probability of obtaining the specified or } \\
\text { lower yield (accumulated frequency),\% }\end{array}$ & Yield, c/ha & $\begin{array}{c}\text { Accumulated } \\
\text { frequency, \% }\end{array}$ & Yield, c/ha & $\begin{array}{c}\text { Accumulated } \\
\text { frequency, \% }\end{array}$ \\
\hline $\mathbf{3 , 0 0}$ & $0,54 \%$ & 20,98 & $18,04 \%$ & 38,96 & $56,76 \%$ \\
\hline $\mathbf{5 , 9 9}$ & $1,62 \%$ & 23,98 & $22,36 \%$ & 41,96 & $64,33 \%$ \\
\hline $\mathbf{8 , 9 9}$ & $3,24 \%$ & 25,95 & $27,04 \%$ & 44,96 & $72,44 \%$ \\
\hline $\mathbf{1 1 , 9 9}$ & $5,40 \%$ & 26,97 & $31,90 \%$ & 47,95 & $81,08 \%$ \\
\hline $\mathbf{1 4 , 9 9}$ & $\mathbf{9} 9$ & 29,97 & $37,31 \%$ & 50,95 & $90,27 \%$ \\
\hline $\mathbf{1 6 , 1 0}$ & $11,01 \%$ & 32,97 & $43,25 \%$ & 53,95 & $100,00 \%$ \\
\hline $\mathbf{1 7 , 9 8}$ & $14,25 \%$ & 35,96 & $49,74 \%$ & 56,94 & $\mathrm{x}$ \\
\hline
\end{tabular}

The information provided illustrates possible events - obtaining a certain level of the yield - and the probability of such events. The cumulative (accumulated) frequency values show the chances of getting the yield at the level indicated in the table or below it. For example, the probability that the grain yield will be $11.99 \mathrm{c} /$ ha (take the closest to the required value) or less is $5.4 \%$.

So, we can say that the probability that the company will not be able to fully cover the costs (debt service costs, production costs), and therefore will not be able to timely and fully pay its financial obligations is $5.4 \%$.

This example shows that taking into account risks leads to the more correct and effective planning of investment activities. The analysis showed that the company might refuse borrowed funds because the percentage of non-return is too small or, on the contrary, to attract more funds for scaling and expanding the business.

\section{Conclusions.}

An increase in the growth rate of production in agriculture is impossible without additional financial investments that stimulate the introduction of innovations. In the market system of management, investment in production is carried out mainly at the expense of their own funds, that is, enterprises' income. However, in conditions when the majority of agricultural enterprises are lowprofit and often unprofitable, the possibilities of self-financing of reproduction processes are limited. The low efficiency of the agricultural business makes it unattractive for investors, especially foreign ones, whose contribution can be expressed not only in cash but also in the form of ultramodern machines, equipment and technologies.

At the same time, agro-industrial production is a probabilistic system, the development of which is associated with the uncertainty of an objective and subjective nature, that is, with risks in their various forms, both macroeconomic and microeconomic levels. The relevance of the topic of risks in the agro-industrial complex is currently recognized not only in scientific circles but also among entrepreneurs, as well as government agencies.

Therefore, along with the existing problems of investment management, the problems of regulation and control of the level of risk become relevant, taking into account the increased requirements for the quality of management of investment activities in the agro-industrial business, which will become a topic for further research.

\section{References}

1. Almazán, D., Tovar, Y., Quintero, J. (2017). Influence of information systems on organizational results. Contaduría y Administración, 62(2), pp. 321-338.

2. Dzwigol, H., Aleinikova, O., Umanska, Y., Shmygol, N., Pushak, Y. (2019). An Entrepreneurship Model for Assessing the Investment Attractiveness of Regions. Journal of Entrepreneurship Education, 22, (SI1), pp. 1-7. Retrieved from https://www.abacademies.org/articles/Anentrepreneurship-model-for-assessing-the-investment-1528-2651-22-S1-339.pdf 
3. Filyppova, S., Bashynska, I., Kholod, B., Prodanova, L., Ivanchenkova, L., Ivanchenkov, V. (2019). Risk management through systematization: Risk Management Culture. International Journal of Recent Technology and Engineering. Volume-8 Issue-3, pp. 6047-6052 DOI: 10.35940/ijrte.C5601.098319

4. Ford, D. (2019). Control Functions in the book Humans as Self-Constructing Living Systems. DOI: 10.4324/9780429025235-11

5. Halkiv, L., Karyy, O., Kulyniak, I., Ohinok, S. (2020). Innovative, scientific and technical activities in Ukraine: Modern trends and forecasts. Proceedings of the 2020 IEEE 3rd International Conference on Data Stream Mining and Processing, DSMP 2020, pp. 321-324, 9204148

6. Korauš, A., Havierniková, K., Gombár, M., Černák, F., Miroslav, F. (2020). Dimensions and their elements affecting the innovative activities of agricultural SMEs toward their sustainable development. Entrepreneurship and Sustainability Issues, 8(2), pp. 1142-1157.

7. Kvasha, S., Pankratova, L., Koval, V., Tamošiuniene, R. (2019). Illicit financial flows in export operations with agricultural products. Intellectual Economics, 13(2), pp. 105-209.

8. Mattila, T., Manninen, M., Rikkonen, P., Kymäläinen, H.-R. (2008). Management of investment processes on Finnish farms. Agricultural and Food Science, 17(1), pp. 18-30. DOI: $10.2137 / 145960608784182263$

9. Merchant, K. (1982). The Control Function of Management. Sloan Management Review, 23(4), pp. 43-55.

10.Oleshko, A. Krasuk,Y., Borysova, M. (2020). Crisis management of investment processes in the national economy. State and regions Series Economics and Business, 1(112), pp. 143-147. DOI: $10.32840 / 1814-1161 / 2020-1-24$

11. Serhienko, V. (2020). Use of system approach in management of investment processes in the agricultural sphere. Market Infrastructure, 50, pp. 54-58. DOI: 10.32843/infrastruct50-9

12.State Statistics Service of Ukraine. http://www.ukrstat.gov.ua/

13. Tworek, P. Behavioural aspects of risk management in investment processes in construction. Ed. Čulik M. Ostrava: VŠB - TU Ostrava, 2014.

14. Winch, D. (2007). Managing the investment process. CFA Digest, 37(2), pp.69-71. DOI: 10.2469/dig.v37.n2.4607

15.Zakharova, O. (2014). Economic study and risk estime of the investment in the human capital. Economics and Sociology, 7(2), pp. 94-108. 